\title{
News, Comments, and Queries
}

\section{In Attemoriam}

Professor Joseph Schnetz died in Günzburg, Germany, in August 1952. With him passed one of the late representatives of the phase of German scholarship at whose threshold stand the Humboldts and the Grimms. Far removed from academic "specialization," from spending a lifetime to a single phase of cultural history, Schnetz strove to contribute his best by devoting his talents to humanistic culture in the widest sense.

Born in 1873 in Wien he came as child to München, which was more or less his home until his death. After his studies at the University he taught at various gymnasia, later at his alma mater, and finally, after World War II, at the newly revived University of Dillingen. The pursuit of research accompanied him through all the years of teaching. His first published scholarly works dealt with Valerius Maximus. But soon he found in the lore of the native flora a fertile field for his investigations. Between 1906 and 1911 he published more than a dozen botanical papers of recognized significance. It almost looks as if a coincidence must have led him to discover the field in which he was to become a leader. In 1912 he published in an obscure local newspaper an article, "Der Romberg bei Sendelbach: Plauderei über seinen Namen." From then on his field was name research, without, to be sure, neglecting his other studies: classical philology, geography, botany.

Schnetz' greatest contribution to the science of onomatology was the founding of Zeitschrift für Ortsnamen in 1925, the first periodical devoted to toponymy on a scholarly and international basis. It later also included in its orbit the phase of anthroponymy and remained the leading journal in the field of name research until it became a victim of the Hitler insanity in 1944 .

It would be futile to attempt to evaluate the 20o-odd contributions by Schnetz to the field of onomastics. Some of his works have programmatic significance and, let us hope, will be translated into English and thus made available to a wider circle. His universality, 
his devotion, his thoroughness will remain a model for young scholars who intend to work in the field in which he was a master.

E. G. G.

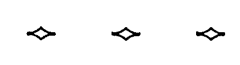

New Works by Tibón.-The publication of two new important books by Gutierre Tibón is imminent: Ensayo de Antroponimia Comparada and Diccionario Etimológico Comparado de los Nombres Proprios de Persona. Tibón is professor at the National University of Mexico and a charter member of our society. Among his former works are Origen, Vida y Milagros de su Apellido and América, Setenta Siglos de la Historia de un Nombre. His position in modern Mexican culture and in the Spanish speaking world in general is outlined by Louis Nesbit in Hispania, February, $195^{\circ}$.

The Names of Connecticut.-Dean Arthur H. Hughes and Professor Morse Allen, both of Trinity College, Hartford, Connecticut, have for some time been engaged in collecting data for an eventual dictionary of Connecticut place names. It is hoped to include all topographical and political subdivision names (except most road and street names) that have appeared in print since the settlement of the colony, and as many name origins as possible.

So far, the names which have appeared on all available maps have been card-indexed, and investigation is proceeding on the information scattered through the many county and town histories and other sources. Eventually it is hoped to ask for the aid of the numerous individuals who have local information concerning the state's 169 towns.

A Bird Name Project.-On field trips more than 40 years ago, W. L. McAtee, enticed by the local names heard especially in eastern North Carolina and Acadian Louisiana, began a collection of the cognomens of birds in America north of Mexico. Through additional field investigations, distribution of questionnaires, and search of literature, the materials grew until they seemed sufficient bases for a manuscript on "American Bird Names: Their Histories and Meanings." The project received support from the United States Fish and Wildlife Service and the University of Chicago Press, at 
which latter institution the completed manuscript awaits subsidization. The contents are some sixty thousand names in fifteen languages which, with a glossarial index, will make two good-sized volumes. One of the purposes of the American Name Society is to publish standard dictionaries of all classes of names. For the time being a subsidy would be necessary to bring out an extensive book like McAtee's "Dictionary of American Bird Names."

Whence Soi-Swah?-On the east coast of Canada a generic spelled soi and pronounced swah is attached to small channels or straits. P. E. Palmer, chairman of the Canadian Board on Geographical Names, would appreciate information regarding the origin and meaning of this geographical term.

Mount Duncan McDuffie.-When the State Geological Survey of California in the $1860^{\prime}$ 's and 1870 's undertook the geodetic survey of the Sierra Nevada, its members made liberal use of their privilege of bestowing names of friends, colleagues, and distinguished scientists upon nameless peaks. This practice of naming orographic features in honor of persons has been continued; descriptive and incidental names are in the minority. The latest mountain to receive a name is the second highest peak of the Black Divide, 13,271 feet high, in King's Canyon National Park. At the suggestion of the Committee on Place Names the directors of the Sierra Club voted to petition the U.S. Board on Geographic Names to have this feature named Mount Duncan McDuffie in memory of one of the outstanding mountaineers and conservationists, who died April 21, 1951 .

Oregon Geographic Names.-A third edition of Lewis McArthur's standard dictionary of Oregon's place names has been announced. The author died in $195^{1}$ before he could finish the revised edition. The final revision was done by Mrs. McArthur.

Presidential Place Name Covers.-The avalanche of new issues of postage stamps which started after World War I has obliged the stamp collector to specialize and limit his hobby to certain countries, types, cancellations, etc. One of our members, William E. Ashton, conceived the idea of a collection of covers, bearing a stamp with 


\section{$13^{6} \quad$ News, Comments and Queries}

the portrait of one of our presidents and the cancellation from a post office named for him. Mr. Ashton soon found that there is not only a bewildering number of post offices in the United States which were named for Washington, or Harrison or Lincoln, but also that there is a great number of post offices which appear to bear the name of a president but actually have an entirely different source. It would not be a genuine collector's item if the seven cents stamp with Jackson's portrait would bear the cancellation of a post office that was named for the first postmaster, whose name happened to be Jackson. Undaunted Mr. Ashton set out to separate the wheat from the chaff. The result is an interesting piece of research which is published serially in the Weekly Philatelic Gossip. Mr. Ashton has not neglected the names which have a suffix like burg or ville, or a generic term like junction or creek. His inclusion of the Christian names of the presidents does not seem to fit in the pattern. A person interested in philately or/and in onomatology will find a wealth of information in these articles.

E. K. G.

The Fight for Kiser Glacier.-A glacier on Mount Baker in the state of Washington has been known for almost half a century as Mazama Glacier, named for the well-known club of mountaineers, the Mazamas. For the last five years a struggle has been waged to change this name to Kiser Glacier. The U. S. Board on Geographic Names could not do anything in this matter for reasons which may be considered fundamental principles of naming orographical or hydrographical features: first, a natural feature which has an established name should not be changed unless the name causes confusion or is otherwise undesirable; second, the name of a living person should not be used as a geographical name. The case was taken to a higher authority, the Congress of the United States. On February 19, 1948, Representative Poulson introduced H. R. 5471 which provided for changing the name of Mazama Glacier to Kiser Glacier. The bill did not pass but was introduced by Representative Poulson at regular intervals. The last bill, H. R. 1061, dated January 6,1953 , reads:

Be it enacted by the Senate and House of Representatives of the United States of America in Congress assembled, That the glacier on Mount Baker in the State of Washington, which is referred to as "Mazama Glacier" or "Kiser Glacier," shall hereafter be known as Kiser Glacier and by that name only. 
To the world at large it does not make any difference whether this glacier is known by the name of Mazama or the name of Kiser. One only wonders that the Congress of the United States spends time and money on the name of a minor geographical feature.

E. G. G.

Professor J. B. Rudnyckyj, chairman of the department of Slavic Studies at the University of Manitoba and a charter member of the $A N S$, has been elected Canadian delegate to the International Committee of Onomastic Sciences.

The Ukrainian Free Academy of Sciences has published monographs 5 and 6 of its series Onomastica: "L'Origine du Nom des Ruthènes" by Boris Unbegaum, professor at the University of Strassbourg, and "Contribution to Methods in Onomastics: Topoand Choronyms and their Origin" by Dr. G. M. Lucyk, of Winnipeg, a charter member of the $A N S$. The latter is written in Ukrainian with an English summary.

Isthmania - a Hoax? - A strange case of attempting to change the name of a country for some reason or another is reported by Donald G. Bouma of Goshen, Indiana, cartographer for the Comprehensive Social Studies Maps of United States.

After spending a great deal of time during November and December of 1949 gathering data on world political boundaries he was ready to publish a World Map which would be up-to-date for January $1,1950$.

On January 24, $195^{\circ}$ a map appeared in the local newspaper showing Guatemala as Isthmania. A box in the map said, "Guatemala changed its name to 'Isthmania' as part of President Juan Arevela's campaign for a Central American Federation of five nations-his country, Honduras, Nicaragua, Costa Rica and El Salvador. The last two support the proposal. Nicaragua and Honduras are opposed." A subtitle under the map said,

“' 'ISTHMANIA' NOW-After February 1 Guatemala will be known as 'Isthmania' according to a government decree. If you write to friends in the Central American republic, be sure to use the new name. After the February 1 deadline, mail from abroad incorrectly addressed to 'Guatemala' will be returned." 
Hesitant to accept such a major name change on the basis of a news release, Bouma immediately dispatched letters to the American Geographic Society in New York, and to the Guatemala embassy in Washington.

The reply from A.G.S. indicated that there was no basis for the report. Moreover, they had called the consul for Guatemala in New York, who had never heard of it. This was enough to ignore the newsmap in the map publication. After the map was printed (without using Isthmania) a reply was received in Spanish from Guatemala where the letter to the embassy had been forwarded. This left no shadow of doubt that the name Guatemala was, is, and forever shall be Guatemala. The force of the language used implied that they were extremely dismayed that their good neighbors to the north could say such things.

This correspondence, together with the clipped news-map was turned over to the editor of the local newspaper who in turn forwarded it to the syndicate which released the map. A few days later, Bouma received a lengthy telegram from the syndicate telling him to ignore the news-map because the information they had received had proved to be unreliable.

Hooters Damm.- John Henry Brown in his Reminiscences and Incidents of "The Early Days" of San Francisco (1886) in telling of an expedition from Fort Hall to California in 1843 makes mention of a place called "Hooters Damm." Can anyone identify this place for me-either the location meant or what the name is supposed to be? Brown was an uneducated Englishman. His spelling of place-names is likely to be weird, and allowance must also be made for his English ear. The only suggestion to be offered so far is that Hooters may be a variant of Utah, which was already in use as a tribal name.

J. H. S.

Names that talk.-Since Wilhelm von Humboldt published in 1821 his epoch-making essay on the place names of the Iberian peninsula as a source for primeval history, place name research has been recognized as an important auxiliary to history. In many cases the roots of geographical names have told us of the existence of people of whom no other evidence remains. In the March, 1953 
issue of the California Historical Society Quarterly, H. F. Raup and William B. Pounds, Jr., published an article, "Northernmost Spanish Frontier in California," in which they show the extent of the exploration and the settlement of Spanish-speaking people on the basis of geographical names. The article shows that if all documentary evidence were destroyed the names would still tell with fair accuracy the extent of the influence of the Spaniards and Mexicans in California.

A Dictionary of American Surnames.-My projected "Dictionary of American Surnames" is the result of an interest in personal names extending back about 35 years.

Until the fall of 1945 , however, it was only a moderate interest. At that time, to fulfill a speech assignment, in an evening class, I gave a talk on the meanings and origins of surnames. The speech took well and I was invited to repeat it before various organizations. Since then I have worked systematically and consistently on my project.

My investigations have been along six broad lines:

1. What my predecessors have written: I have read everything about surnames, in any language, that has been available to me as well as many books about forenames and place-names. I still lack many out-of-print books. At present I feel a particular need for books about Irish, German, and Slavic surnames.

2. Linguistics: Proper nouns are a part of language, and anyone who sets out to write about them should be as well grounded in linguistics as a writer on any other phase of language.

3. Which surnames are the most common: I have determined which are the 1800 most common American surnames. In addition, for the 563 most common I have calculated their rate of incidence per 100,000 persons. For these names I intend to include these figures and to number them in the order of their importance.

4. Other branches of knowledge: A proper definition of many surnames, and surnames in general has required investigation into many fields such as anthropology, hagiology, religious history, mythology, human geography, historical geography, history in general, and antiquities.

5. Directories: I am accumulating a library of name-lists, usually telephone directories, of every European country as a guide to basic 
forms. I have had good success in obtaining these but, with the exception of Estonia, I have been able to obtain nothing from behind the Iron Curtain. I have many American telephone directories but need more.

6. Newspapers and periodicals: A surprising amount of onomastic and other linguistic material appears in the popular press.

I will be pleased to hear from anyone who is in any way interested in my project. I am interested in buying any research material which I do not have. I am willing to borrow anything that is not for sale.

R. D. ROBERTS

Southwest Words.-While traveling through the Southwest my inquiring mind was in constant turmoil over words like Agathla, Betatakin, Chiricahua, Hovenweep, Kaiparowits, Shipaulovi,Sichomovi, Dawa Mana Humetewa, Poli Payestewa, El Rito de Los Frijoles, Tyuonyi, Cachiti, Tiguex, Wupatki, Parunuweap, and a thousand and one more which have a definite and important place in the Southwest world. I decided to do something about it. I would put my findings into a book, not just another one, but a book like the one I wanted to get hold of but never could find. I talked my problem over with Southwest educators, authors, publishers, societies and travelers. They all encouraged me to write such a book, a single volume on the whole area, one which would serve the school, the layman, the tourist, and perhaps the scientific student. To date I have only classified the words, hundreds of them, alphabetically. Later on I shall classify them as Indian, Spanish, and Anglo. Of course the Anglo words will have a peculiar southwest flavor, spiced up with a dash of chili or Mexican sauce. I am sure that a book of this nature, providing it is done on a high plane, will fill a definite need. 